Science, Technology and Development 35 (1): 47-50, 2016

ISSN 0254-6418 / DOI: 10.3923/std.2016.47.50

(C) 2016 Pakistan Council for Science and Technology

\title{
Flowering Quality of Polianthus tuberosa var. Fancy white as Affected by Planting Dates in Agro Metrological Conditions of Islamabad
}

\author{
${ }^{1}$ Samia Ikram, ${ }^{1}$ Noor Alam Khan, ${ }^{2}$ Alam Syed Shah Mahsud and ${ }^{1}$ Saima Mumtaz \\ ${ }^{1}$ Horticultural Research Institute, National Agricultural Research Centre, Islamabad, Pakistan \\ ${ }^{2}$ Department of Horticulture, Faculty of Agriculture, Gomal University, Dera Ismail Khan, Pakistan
}

\begin{abstract}
The research study was conducted to investigate the effect of different planting dates on the flowering quality of Polianthus tuberosa in agro metrological conditions of Islamabad. The experiment was laid out in the research field of Floriculture programme, Horticultural Research Institute (HRI), National Agricultural Research Centre (NARC), Islamabad, during March, 2014 to May, 2014. The tuberose bulbs of approximately three $\mathrm{cm}$ size were sown with a week's interval, starting from 19th March to 7th May, 2014, containing eight treatments in total, each of which was replicated three times. The statistical analysis at $5 \%$ LSD revealed that less days to emergence were taken by $\mathrm{T}_{4}$ (2.88 days), maximum plant height was noted in $\mathrm{T}_{6}(56.18 \mathrm{~cm})$, maximum plant spread was $60.18 \mathrm{~cm}$, maximum number of recorded leaves was 45.42 , the spike length of $107.71 \mathrm{~cm}$ and most number of florets per spike (35.02) were recorded in $\mathrm{T}_{4}$. Maximum spike diameter $(2.40 \mathrm{~cm})$ was observed in $\mathrm{T}_{2}$, while flower diameter of $3.11 \mathrm{~cm}$ was contributed by $\mathrm{T}_{5}$. The study revealed that the best planting time that contributed to maximum quality parameters was $\mathrm{T}_{4}$ (9th April 2014).
\end{abstract}

Key words: Tuberose, planting dates, spike, flower, quality

\section{INTRODUCTION}

Tuberose is a flower acknowledged around the globe for its scent, appealing beauty value, shelf life and its essential oil extracts (Singh, 1995). It is native of Mexico and is commonly cultivated in tropical and subtropical part of the biosphere for its growing consumer demand (Jowkar and Salehi, 2006; Benschop, 1993; Huang et al., 2000). It nurtures well in central America and India and is very much in demand in the countries of the Indian subcontinent, middle East and Africa for making of perfumes. In plains of Pakistan, it blooms profusely during the summer and flaunts its fragrance indoor and outdoor. As a cut flower it has maximum shelf life (about one month) among the cut flowers.

Tuberose performs well in light acidic to neutral soil $\mathrm{pH}$ (6.5-7.5) with soil texture loamy and sandy loam (Sharga and Sharma, 1994). Change in temperature significantly affects its growth and flowering. Mostly propagated by means of corms, with most suitable diameter 2.5-3.5 cm and planting depth $6.0 \mathrm{~cm}$ for cut flower production (Hussain, 1999).

Planting dates play a vital role in regulating growth and quality of tuberose, though it has a long planting period. Vegetative growth and quality of tuberose is improved by early plantings (Khobragade et al., 1997). Tuberose is usually planted in 2nd and 3rd month of the year (February-March) in the plain areas and in 4th and 5th month of the year (April-May) in the mountains. The highest numbers of spikes per plant were recorded from April-May whereas, the highest numbers of corms per plants were obtained during March and April (Mubhopadhayay and Banker, 1881). Singh et al. (1999) observed the longest and maximum number of flower spike per clump and maximum number and size of corms per plant from June planting. The highest flower yield was obtained from mid August to mid November plantings (Zizzo et al., 1998). Planting dates have noteworthy effect on germination of gladiolus corm (Adil et al., 2013). It has a great economic potential for cut-flower trade and essential oil industry reported by Panigrahi and Saiyad (2013). Planting between last week of March and first week of April is recommended for good growth, best cut-flower and more corms production of tuberose (Asif et al., 2001). Current study was designed to investigate best planting time contributing to better quality tuberose flower under agro-climatic conditions of Islamabad.

\section{MATERIALS AND METHODS}

The experiment was conducted in the research fields of Floriculture program, Horticultural Research Institute (HRI), National Agricultural Research Centre (NARC), Islamabad. In this experiment, effect of eight planting dates was studied on Polianthus tuberosa in 
agro-metrological conditions of Islamabad. Healthy bulbs were planted at a week's interval (March-May, 2014) in well prepared plot of $2 \mathrm{~m}^{2}$ keeping plant×plant and row-to-row distance 6 inches and 1 foot, respectively, following Randomized Complete Block Design (RCBD). The experiment was replicated 3 times with 10 plants in each replication. The planting dates used as treatments are mentioned in Table 1 and 2.

Traits studied: The vegetative, reproductive and quality parameters were studied as days to emergence, plant height $(\mathrm{cm})$, plant spread $(\mathrm{cm})$, number of leaves, spike length $(\mathrm{cm})$, spike diameter $(\mathrm{cm})$, number of florets per spike and flower diameter with standard procedures (AOAC., 1990).

Statistical analysis: The experiment was laid down, using linear model Randomized Complete Block Design (RCBD). The collected observations were analyzed, using Statistica. The means were compared, using the Least Significant Difference (LSD) at 5\% probability level (Steel et al., 1997).

Table 1: Different planting dates for Polianthus tuberosa var. Fancy white

\begin{tabular}{|c|c|}
\hline Treatments & Planting dates \\
\hline $\mathrm{T}_{1}$ & 19th March, 2014 \\
\hline $\mathrm{T}_{2}$ & 26th March, 2014 \\
\hline $\mathrm{T}_{3}$ & 2nd April, 2014 \\
\hline $\mathrm{T}_{4}$ & 9th April, 2014 \\
\hline $\mathrm{T}_{5}$ & 16th April, 2014 \\
\hline $\mathrm{T}_{6}$ & 23rd April, 2014 \\
\hline $\mathrm{T}_{7}$ & 30th April, 2014 \\
\hline $\mathrm{T}_{8}$ & 7th May, 2014 \\
\hline
\end{tabular}

\section{RESULTS AND DISCUSSION}

The statistical data related days to emergence (Table 3) reveals that minimum days for emergence (2.88) were taken by $\mathrm{T}_{4}$ and maximum days for emergence were counted for $T_{1}$ (6.23). Minimum days taken by tuberose to emerge were recorded for $T_{4}$ followed by $T_{7} T_{5} T_{6} T_{2} T_{8}$ $T_{3} T_{1}$ (Table 3). As per metrological data it was observed that maximum temperature facilitates early sprouting in bulbous plants (Arora and Sandhu, 1987). Hong et al. (1989) and Ahmad et al. (2011), who stated that delay in planting decreased the number of days to sprouting. This statement is in agreement with this results as the possible reason for which may be increased temperature that facilitates emergence. Maximum plant height $(56.18 \mathrm{~cm})$ was observed in $T_{6}$, while the lowest plant's height of $39.95 \mathrm{~cm}$ was recorded for $\mathrm{T}_{1}$. The maximum plant heights were produced when the bulbs of tuberose were sown at the end days of April followed by $T_{8} T_{2} T_{7} T_{3} T_{5}$ $\mathrm{T}_{4} \mathrm{~T}_{1}$ (Table 3). The maximum plant height recorded may be due to the favourable time for photosynthesis, which contributed to maximum height and well developed structure as previously reported by Ko et al. (1994). Khan et al. (2008) also reported that planting dates significantly affected vegetative growth in Tulip. The statistical data on plant spread showed that maximum plant spread is contributed by $\mathrm{T}_{4}(60.81 \mathrm{~cm})$ followed by $\mathrm{T}_{3} \mathrm{~T}_{6} \mathrm{~T}_{8} \mathrm{~T}_{1} \mathrm{~T}_{2} \mathrm{~T}_{5}$ (Table 3) and lowest spread (49.17 cm) was recorded in $T_{7}$. The maximum plant spread is an indicator of vegetative growth, which may be due to the favourable environmental conditions as previously reported by Ko et al. (1994) in gladiolus plants.

Table 2: Average metrological data from 19th March- 14th May 2014**

\begin{tabular}{|c|c|c|c|c|c|}
\hline Treatments & Weeks & $\begin{array}{l}\text { Avgerage } \\
\text { maximum temp }\left({ }^{\circ} \mathrm{C}\right)\end{array}$ & $\begin{array}{l}\text { Avgerage } \\
\text { minimum temp }\left({ }^{\circ} \mathrm{C}\right)\end{array}$ & $\begin{array}{l}\text { Avgerage } \\
\text { rainfall (mm) }\end{array}$ & $\begin{array}{l}\text { Avgerage relative } \\
\text { humidity }(\%)\end{array}$ \\
\hline $\mathrm{T}_{1}$ & 19th-25th March, 2014 & 22.125 & 10.125 & 29.69 & 78.25 \\
\hline $\mathrm{T}_{2}$ & 26th March-1st April, 2014 & 22.80 & 10.40 & 13.61 & 77.70 \\
\hline $\mathrm{T}_{3}$ & 2nd-8th April, 2014 & 23.57 & 13.71 & 2.57 & 78.79 \\
\hline $\mathrm{T}_{4}$ & 9th-15th April, 2014 & 27.57 & 12.14 & 0.00 & 64.21 \\
\hline $\mathrm{T}_{5}$ & 16th-22nd April, 2014 & 25.57 & 13.29 & 1.68 & 69.86 \\
\hline $\mathrm{T}_{6}$ & 23rd-29th April, 2014 & 33.00 & 15.00 & 0.00 & 54.71 \\
\hline $\mathrm{T}_{7}$ & 30th April-6th May, 2014 & 23.57 & 13.71 & 2.57 & 78.79 \\
\hline $\mathrm{T}_{8}$ & 7th-14th May, 2014 & 25.46 & 12.63 & 0.00 & 71.60 \\
\hline
\end{tabular}

Table 3: Different parameters of Polianthus tuberosa var. Fancy white as affected by planting dates

\begin{tabular}{|c|c|c|c|c|c|c|c|c|}
\hline Treatments & $\begin{array}{l}\text { Days to } \\
\text { emergence }\end{array}$ & $\begin{array}{l}\text { Plant } \\
\text { height }(\mathrm{cm})\end{array}$ & $\begin{array}{l}\text { Plant } \\
\text { spread (cm) }\end{array}$ & $\begin{array}{l}\text { Number } \\
\text { of leaves }\end{array}$ & $\begin{array}{l}\text { Spike } \\
\text { length }(\mathrm{cm})\end{array}$ & $\begin{array}{l}\text { Spike } \\
\text { diameter }(\mathrm{cm})\end{array}$ & $\begin{array}{l}\text { No. of } \\
\text { florets }\end{array}$ & $\begin{array}{l}\text { Flower } \\
\text { diameter }(\mathrm{cm})\end{array}$ \\
\hline $\mathrm{T}_{1}$ & $6.23 \pm 0.30^{\mathrm{a}}$ & $39.95 \pm 1.67^{\mathrm{e}}$ & $52.90 \pm 0.70^{\text {cd }}$ & $25.10 \pm 0.08^{g}$ & $81.04 \pm 0.38^{\mathrm{g}}$ & $1.85 \pm 0.05^{\mathrm{d}}$ & $17.59 \pm 0.08^{f}$ & $2.21 \pm 0.14^{\mathrm{d}}$ \\
\hline $\mathrm{T}_{2}$ & $4.35 \pm 0.56^{c}$ & $50.78 \pm 1.45^{\mathrm{b}}$ & $52.25 \pm 0.50^{\mathrm{d}}$ & $38.22 \pm 0.43^{\mathrm{e}}$ & $98.20 \pm 0.60^{b}$ & $2.40 \pm 0.33^{\mathrm{a}}$ & $22.25 \pm 0.52^{\mathrm{e}}$ & $2.7 \pm 0.58^{\mathrm{abc}}$ \\
\hline $\mathrm{T}_{3}$ & $5.34 \pm 0.34^{b}$ & $47.05 \pm 0.50^{c}$ & $56.05 \pm 0.21^{\mathrm{b}}$ & $42.18 \pm 0.30^{\mathrm{b}}$ & $92.80 \pm 0.39^{\mathrm{e}}$ & $1.9 \pm 0.50^{\mathrm{cd}}$ & $16.36 \pm 0.45^{\mathrm{g}}$ & $2.21 \pm 0.05^{\mathrm{cd}}$ \\
\hline $\mathrm{T}_{4}$ & $2.88 \pm 0.12^{\mathrm{d}}$ & $42.61 \pm 0.62^{\mathrm{d}}$ & $60.81 \pm 0.46^{a}$ & $45.42 \pm 0.54^{\mathrm{a}}$ & $107.71 \pm 0.51^{\mathrm{a}}$ & $2.12 \pm 0.06^{\mathrm{bc}}$ & $35.02 \pm 0.42^{\mathrm{a}}$ & $2.72 \pm 0.42^{\mathrm{abc}}$ \\
\hline $\mathrm{T}_{5}$ & $3.31 \pm 0.16^{\mathrm{d}}$ & $45.18 \pm 0.90^{c}$ & $50.20 \pm 0.56^{e}$ & $41.27 \pm 0.24^{\mathrm{c}}$ & $97.46 \pm 0.21^{\mathrm{b}}$ & $2.12 \pm 0.08^{\mathrm{bc}}$ & $24.34 \pm 0.26^{\mathrm{d}}$ & $3.11 \pm 0.12^{\mathrm{a}}$ \\
\hline $\mathrm{T}_{6}$ & $4.18 \pm 0.17^{c}$ & $56.18 \pm 0.71^{\mathrm{a}}$ & $55.59 \pm 0.65^{b}$ & $31.72 \pm 0.14^{\mathrm{f}}$ & $84.43 \pm 0.35^{f}$ & $2.04 \pm 0.02^{\text {bcd }}$ & $22.34 \pm 0.37^{e}$ & $2.42 \pm 0.12^{\mathrm{bcd}}$ \\
\hline $\mathrm{T}_{7}$ & $3.18 \pm 0.16^{c}$ & $49.55 \pm 0.85^{b}$ & $49.17 \pm 0.24^{\mathrm{e}}$ & $39.92 \pm 0.81^{\mathrm{d}}$ & $96.62 \pm 0.38^{c}$ & $2.11 \pm 0.03^{\mathrm{bc}}$ & $25.30 \pm 0.38^{c}$ & $2.85 \pm 0.06^{\mathrm{ab}}$ \\
\hline $\mathrm{T}_{8}$ & $4.61 \pm 0.12^{c}$ & $55.08 \pm 1.02^{\mathrm{a}}$ & $53.65 \pm 0.55^{c}$ & $17.35 \pm 0.57^{\mathrm{h}}$ & $94.35 \pm 0.25^{\mathrm{d}}$ & $2.18 \pm 0.01^{\mathrm{ab}}$ & $26.44 \pm 0.61^{\mathrm{b}}$ & $2.86 \pm 0.03^{\mathrm{ab}}$ \\
\hline LSD & 0.24 & 0.89 & 0.49 & 0.36 & 0.35 & 0.10 & 0.31 & 0.23 \\
\hline
\end{tabular}


Sci. Technol. Dev., 35 (1): 47-50, 2016

Table 4: Analysis of variance for different parameters of Polianthus tuberosa var. Fancy white as affected by planting dates

\begin{tabular}{lllccccccc}
\hline Source of variance & $\mathrm{df}$ & Emergence & Flower diameter & Plant height & No. of florets & Stem diameter & Spike length & No. of leaves & Plant spread \\
\hline Replication & 2 & 0.052 & 0.05 & 0.32 & 0.38 & 0.002 & 0.05 & 0.299 & 0.17 \\
Error & 7 & $4.077^{* *}$ & $0.29^{*}$ & $98.05^{* *}$ & $100.15^{* *}$ & $0.08^{*}$ & $208.07^{* *}$ & 280.29 & $40.73^{* *}$ \\
Treatment & 14 & 0.09 & 0.08 & 1.19 & 0.147 & 0.01 & 0.189 & 0.193 & 0.37 \\
\hline
\end{tabular}

*Indicates level of significance, ${ }^{* *}$ Indicates high level of significance

Maximum number of plant leaves (45.42) were counted for $\mathrm{T} 4$ followed by $\mathrm{T}_{3} \mathrm{~T}_{5} \mathrm{~T}_{7} \mathrm{~T}_{2} \mathrm{~T}_{6} \mathrm{~T}_{1}$ (Table 3), while lowest number of leaves were counted for $T_{8}$ (17.35). Maximum spike length of tuberose was recorded for $T_{4}$ (107.71 cm) followed by $T_{5} T_{2} T_{7} T_{8} T_{3} T_{6}$ (Table 3), whereas the smallest spike length was observed for $T_{1}$ $(81.04 \mathrm{~cm})$. The findings are in line with the previous findings of Ko et al. (1994), who reported that plants might attain supreme proficiency for improvement due to ideal condition and Adil et al. (2013), who reported maximum plant leaves grown under warm and long days. Khan et al. (2008), further confirmed it by their study on tulip, that was significantly affected by planting time. The data of spike diameter reveals that the highest values were obtained for $\mathrm{T}_{2}(2.40 \mathrm{~cm})$ followed by $\mathrm{T}_{8}>\mathrm{T}_{4}>\mathrm{T}_{5}>\mathrm{T}_{7}>\mathrm{T}_{3}>\mathrm{T}_{6}$ (Table 3), while minimum values were recorded for $T_{1}(1.85 \mathrm{~cm})$. The maximum number of florets per spike were counted for $\mathrm{T}_{4}$ (35.02), followed by $\mathrm{T}_{8}>\mathrm{T}_{7}>\mathrm{T}_{5}>\mathrm{T}_{6}>\mathrm{T}_{1}>\mathrm{T}_{2}$ (Table 3), while minimum florets were counted for $T_{1}(1.85)$. These results are in agreement with Larson (1992), who reported higher number of florets per spike when planted under hot weather conditions. These results also show that maximum floret diameter was recorded for $\mathrm{T}_{5}(3.11 \mathrm{~cm})$, followed by $\mathrm{T}_{8}>\mathrm{T}_{7}>\mathrm{T}_{4}>\mathrm{T}_{2}>\mathrm{T}_{6}>\mathrm{T}_{3}$ (Table 3) and minimum floret diameter was observed for $T_{1}(2.21 \mathrm{~cm})$ and the results of our findings are in line with the previous study of Parker and Borthwick (1980) and Adil et al. (2013), who reported that higher temperature contributed because of high production of photosynthates.

Table 4 describes the analysis of variance for different parameters of Polianthus tuberosa var. Fancy white as affected by planting dates.

\section{CONCLUSION}

On the basis of present study it can be concluded that the best planting time for plantation of tuberose was starting from 2nd week of April (9th April) that contributes to maximum vigour and flower quality.

\section{REFERENCES}

AOAC., 1990. Official Methods of Analysis. 16th Edn., AOAC., Washington, DC. USA., Pages: 1298.
Adil, M., W. Ahmad, K.S. Ahmad, J. Shafi and M.A. Shehzad et al., 2013. Effect of different planting dates on growth and development of Gladiolus grandiflorus under the ecological conditions of Faisalabad, Pakistan. Univ. J. Agric. Res., 1: 110-117.

Ahmad, I., A.M. Khattak, N. Ara and N.U. Amin, 2011. Effect of planting dates on the growth of gladiolus corms in Peshawar. Sarhad J. Agric., 27: 195-199.

Arora, J.S. and G.S. Sandhu, 1987. Effect of two planting dates on the performance of fifteen Gladiolus cultivars. Punjab Hort. J., 27: 243-249.

Asif, M., M. Qasim and G. Mustafa, 2001. Effect of planting dates on growth, flowering and corm characteristics of tuberose (Polianthes tuberosa) cv. single. Int. J. Agric. Biol., 3: 391-393.

Benschop, M., 1993. Polianthes. In: The Physiology of Flower Bulbs, De Hertogh, A. and M. Le Nard (Eds.). Elsevier Publ., Amsterdam, The Netherlands, pp: 589-601.

Hong, Y.P., D.H. Goo and K.Y. Huh, 1989. Studies on corm formation of Gladiolus gandavensis. 3; Effects of planting time of cormels on the corm production, dormancy and flowering of corm in next generation. Res. Rep. Rural Dev. Administrat. Hort., 31: 54-59.

Huang, K.L., I. Miyajima, H. Okubo, T.M. Shen and T.S. Huang, 2000. Breeding of colored tuberose (Polianthes) and cultural experiments in Taiwan. Acta Hort., 570: 367-371.

Hussain, S., 1999. Effect of bulb size and depth of planting on growth and flowering of tuberose (Polianthes tuberose L.) cv. single. M.Sc. Thesis, Department of Horticulture, University of Agriculture, Faisalabad, Pakistan.

Jowkar, M.M. and H. Salehi, 2006. The effects of different preservative solutions on the vase life of cut tuberose (Polianthes tuberose L.) cv. Goldorosht-eMahallat. J. Water Soil Sci., 10: 299-309.

Khan, F.U., A.Q. Jhon, F.A. Khan and M.M. Mir, 2008. Effect of planting time on flowering and bulb production of tulip conditions in Kashmir. Ind. J. Hort., 65: 79-82.

Khobragade, R.I., M.M. Damke, B.J. Jadhao and C.V. Heddau, 1997. Effect of planting time and spacing on growth, flowering and bulb production of tuberose cv. single. Department of Horticulture Dr. ADKV, Akola, India. 
Ko, J.Y., S.K. Kim, N.Y. Um, J.S. Han and K.K. Lee, 1994. Planting times and corm grades of Gladiolus gandavensis for retarding culture in highland RDA. J. Agric. Sci. Hort., 36: 430-434.

Larson, R.A., 1992. Introduction to Floriculture. 2nd Edn., Acadmic Press, London, pp: 147.

Mubhopadhayay, A. and G.J. Banker, 1981. Effect of time of planting on growth, flowering and bulb production in tuberose cv. single. Indian Inst. Hort. Res. Absts., 52: 55-92.

Panigrahi, J. and M.S.L. Saiyad, 2013. In vitro propagation of Polianthes tuberosa L. cultivars (calcutta single). Int. J. Plant Anim. Environ. Sci., 3: 76-79.

Parker, M.W. and H.A. Borthwick, 1980. Day-length proved vital factor in gladiolus flowering. Florirts Exchange, 117: 38-40.

Sharga, A.N. and S.C. Sharma, 1994. Commercial Cultivation of Tuberose. In: Floriculture Tech. Trades and Trends, Prokash, J. and K. R. Bhandary (Eds.). Mohan Primlani for Oxford IBH Publishing Co. Pvt. Ltd., India, pp: 160-167.
Singh, K.P., 1995. Improved production technologies for tuberose (Polianthes tuberosa Linn.). A review of research done in India. Agric. Rev., 16: 141-166.

Singh, P.V., M. Kumar and M. Kumar, 1999. Effect of spacing, depth and time of planting on growth, flowering and bulb production of tuberose cv. double. Department of Hort. C.C.S. Univ. Meerut. India (CAB Abst., 1998/08-200/04).

Steel, R.G.D., J.H. Torrie and M.A. Boston, 1997. Principles and Procedures of Statistics: A Biometrical Approach. 3rd Edn., McGraw Hill Book Company Inc., New York, Pages: 633.

Zizzo, G.V., G. Fascella and S. Angello, 1998. The Effect of Planting Time on the Flowering of Tuberose (Polianthes tuberosa). Institute to Perimentate Per La Floricultura, Italy. 